\title{
Impact Of Eating Habits And Physical Activity On The Fertility Of Females
}

\author{
Faiza Alam ${ }^{1}$, Saba Tariq $^{2}$, Fatima Syed $^{3}$, Sundus Tariq $^{4}$, Rehana Rehman $^{5^{*}}$ \\ ${ }^{1}$ PAPRSB Institute of Health Sciences, Universiti Brunei Darussalam, Bandar Seri Begawan, Brunei \\ ${ }^{2}$ Department of Pharmacology, The University of Faisalabad, Faisalabad, Pakistan \\ ${ }^{3}$ Department of Internal Medicine, Aga Khan University, Karachi, Pakistan \\ ${ }^{4}$ Department of Physiology, The University of Faisalabad, Faisalabad, Pakistan \\ ${ }^{5}$ Department of Biological and Biomedical Sciences, Aga Khan University, Karachi, Pakistan
}

Received: November 3, 2021 Accepted: December 10, 2021 DOI: $10.46568 /$ bios.v2i2.53

\begin{abstract}
:
Introduction: This study aimed to compare the eating habits and the level of activity in fertile and infertile female subjects. Methods: This cross-sectional study was designed to compare the eating habits and level of activity in fertile and infertile female subjects from February 2016 till October 2017. Fertile females $(n=207)$ and diagnosed infertile (infertile, $n=135)$ between $18-40$ years were enrolled. Guidelines for the diagnosis of the infertile cohort were the failure to conceive after 12 months of regular and non-contraception intercourse, with normal uterine structure. Questionnaire was used to collect information regarding nutrition and physical activity. Statistical analysis was carried out employing IBM Statistical Package for the Social Sciences. The categorical variables were presented as frequency and percentages, Chisquare test was performed for comparison, $\mathrm{p}$ value $<0.05$ considered significant. Results: With mean age of $31 \pm 6$ years and mean BMI of $24.6 \pm$ $3.46 \mathrm{~kg} / \mathrm{m}^{2}$, infertile females had a significantly high BMI compared with the fertile females. Physical activity of subjects demonstrated that $30.4 \%$ were inactive, while $27.2 \%$ were physically active. Infertile females $(6.5 \%)$ did regular exercise however, $44.9 \%$ of the fertile females had healthy lifestyle. Females $(51 \%)$ took meals 3 times a day. Healthy food consumption was once a week while $35 \%$ had consumption of fast food was approximately twice a week. Conclusion: Optimal physical activity and BMI in normal range is positively associated with fertility. Dietary habits such as more intake of fish, fruits and vegetables impacts fertility positively.
\end{abstract}

Keywords: Female infertility, Healthy diet, Physical activity, Body mass index

*Correspondence: Bushra Manzoor Lodhi, Department of Biological and Biomedical Sciences, Aga Khan University, Karachi, Pakistan. Contact: +92 3072227775 Fax: 922134894394 Email: drrehana7@gmail.com

\section{Introduction}

Infertility is the inability to acquire pregnancy after one year of regular intercourse without any protection [1]. On an estimate, $15 \%$ of couples are infertile in the general population and about a million of couples opt for advanced reproductive techniques (ART) which are tiresome, laborious and high-priced. In addition to that, failure to conceive after ART has an impact on psychological well-being and is associated with increase in depression and anxiety [2].

Infertility is subject to interplay of genetic factors, hormonal interaction, environmental influences and life style dynamics [1]. Clinical studies have supported a relationship of lifestyle, environment, and female reproductive health in relevance with ovulatory disorders, tubal factors, endometriosis, and unexplained infertility [3]. The mechanisms of action have further been explained with the help of animal models [3]. 
Obesity is one of the lifestyle-related risk factors with increased incidence of number of obese infertile females booked for ART procedures like in vitro fertilization (IVF) and intra cytoplasmic sperm injection (ICSI) [4]. Higher IVF cancellation rates than normal-weight control subjects and greater risk of obstetric complications has also been reported [5] The trend of intake of unhealthy foods like fast food, soft drinks, sweets, and junk food in adolescent girls with polycystic ovarian syndrome (PCOS) has aggravated the clinical symptoms and associated risks in these patients [3]. Oxidative stress and inflammation are common underlying mediators of infertility in many lifestyle practices [6]. At the same time, nutritional insufficiency due to inappropriate food habits and low protein intake, influence the neuroendocrine mechanisms and effect the gonadotrophin releasing hormone $(\mathrm{GnRH})$ and cascade of hormone release [3].

Literature recommends that stress free life, normal daily-life activities and adequate sleep enhance chances of successful conception [7]. A protective effect of physical activity (PA) on fertility regardless of changes in Body Mass Index (BMI) and Waist Hip ratio (WHR) has been observed [8]. Study on 'Impact of Diet, Exercise, and Lifestyle (IDEAL)' facilitates importance of understanding associations between lifestyle factors of couple with the infertility treatment outcomes. International recommendations for lifestyle management to improve reproductive outcomes are; diet lower in glycemic load, higher intakes of fruit, minimal intake of fast food and sugar sweetened beverages [9]. Several studies have revealed that weight loss by diet, PA and/or behavior intervention not only improve body composition, insulin resistance (IR) and hyperandrogenism but restores menstrual regularity and ovulation in overweight or obese women with PCOS [3]. With the aim to know about nutritional status and engagement in PA, our objective is to compare the eating habits and the level of activity in fertile and infertile female subjects.

\section{Materials and Methods:}

This cross-sectional study was conducted at Aga Khan University in collaboration with Australian Concept Infertility Medical Centre (ACIMC), Karachi, Pakistan, from February 2016 till October 2017, after an approval from the ethical approval was obtained from the Review Committee of Aga Khan University (Ref \# 4426-BBS-ERC-16). The sample size of 320 was computed in Open Epi software version 3. With acceptable power of $80 \%$ and detectable odds ratio of at least 2, assumed hypothetical proportion of control with exposure of $22 \%$, prevalence of infertility considered to be $23 \%$ and with $5 \%$ two-sided confidence (1-alpha), the sample size was computed to be 320 females [10]. At the time of enrollment, 342 females were recruited and a signed written informed consent was obtained from all study subjects. One hundred and thirty-five infertile females and two hundred and seven healthy fertile subjects were enrolled in the study

\section{Inclusion Criteria:}

Apparently healthy females bearing a child of 2 years or less, with age ranging from $18-40$ years belonging to any ethnic background of Pakistan, were enrolled as fertile controls group $(n=207)$. However, females with age range of 18 - 40 years from any ethnic background of Pakistan and had not conceived in the last 12 months by regular unprotected relationship were grouped as infertile $(n=135)$.

\section{Exclusion Criteria:}

All study subjects (whether cases or control) were excluded if they had a history of hypertension, pre-existing diabetes, gestational diabetes, or any inflammatory condition. Additionally, females having previous pregnancies through assisted contraception, history of recurrent miscarriages, thyroid problems, gynecological tumors, or serious general health status, taking oral contraceptives or hormonal support or employing any sort of contraceptives were also excluded from the study. 
A questionnaire was filled by the investigator from all the participants when they came to the clinic at ACIMC which inquired about their eating habits pertaining to what item they consume and at what frequency. Similar questionnaire was employed to inquire about their level of PA. The infertile females were further stratified on the basis of prediagnoses of cause of infertility (PCOS, male factor, endometriosis, tubal factors, unexplained) to observe the level of physical activity among them.

\section{Statistical analysis:}

Statistical analysis was carried out employing Statistical Package for the Social Sciences (IBM, SPSS version 21; IBM Corp Inc., Armonk, NY, USA). The categorical variables were presented as frequency and percentages. Chi-square test was performed for categorical variables comparison and $\mathrm{p}$ value was considered significant where less than 0.05 .

\section{Results:}

The mean age of study subjects was $31 \pm 6$ years. There was no significant variance noted between the two groups with respect to age, weight and blood pressure recordings. Mean BMI of overall subjects being $24.6 \pm 3.46 \mathrm{~kg} / \mathrm{m}^{2}$, infertile females had a significantly high BMI compared with the fertile females. Using the South Asian criteria of BMI [11] for stratifying all the study subjects, $34.5 \%, 24.3 \%$ and $41.2 \%$ females were found to be normal weight, overweight and obese, respectively. Table 1 shows the distribution of the fertile and infertile subjects according to their BMI (Table: 1).

Table 1: Comparison of BMI of fertile and infertile subjects

\begin{tabular}{|c|c|c|c|}
\hline Variables & $\begin{array}{c}\text { Fertile }(\mathbf{n}=207) \\
\text { n }(\%)\end{array}$ & $\begin{array}{c}\text { Infertile }(\mathbf{n}=135) \\
n(\%)\end{array}$ & $P$ value \\
\hline Normal weight $\left(<23 \mathrm{~kg} / \mathrm{m}^{2}\right)$ & $72(34.8 \%)$ & $52(38.5 \%)$ & \multirow{3}{*}{0.015} \\
\hline Overweight $\left(23-24.9 \mathrm{~kg} / \mathrm{m}^{2}\right)$ & $58(28 \%)$ & $20(14.8 \%)$ & \\
\hline Obese $\left(>25 \mathrm{~kg} / \mathrm{m}^{2}\right)$ & $77(37.2 \%)$ & $63(46.7 \%)$ & \\
\hline
\end{tabular}

Values expressed as $\mathrm{n}(\%)$. Groups compared by Pearson Chi Square test; where $\mathrm{p}<0.05$ is considered significant. $\mathrm{BMI}=$ body mass index

Level of activity of all subjects demonstrated that $30.4 \%(\mathrm{n}=104)$ did not have any practice of walking at all during a week, while $27.2 \%(n=93)$ coped with walking more than half an hour every day. Among all infertile subjects, around $66.5 \%(\mathrm{n}=90)$ did not have a habit of walking though, $39.6 \%(n=81)$ and $44.9 \%(n=93)$ of the fertile females walked 30 mins 5 times a week and more than half an hour every day, respectively (Figure 1). 


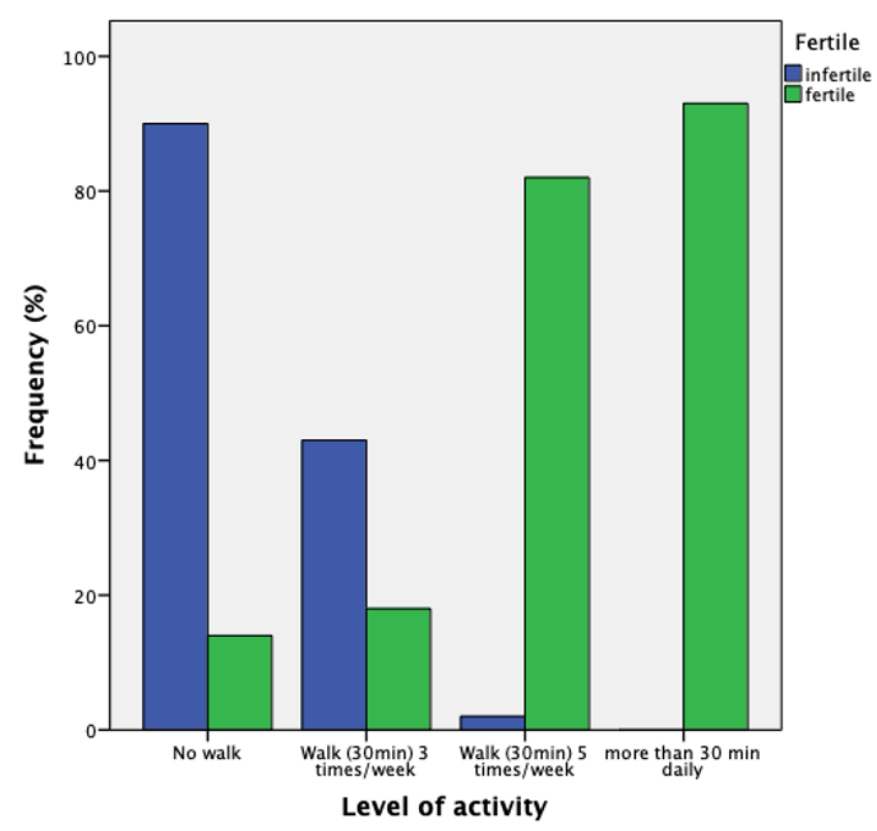

Figure 1: Comparison of activity level among fertile and infertile females.

The frequency of meals was noted to be normal ( 3 times a day) in $51 \%$ of overall subjects. Consumption of healthy food items was mostly just once a week while $35 \%$ consumption of snack food was approximately twice in a month (Figure 2).

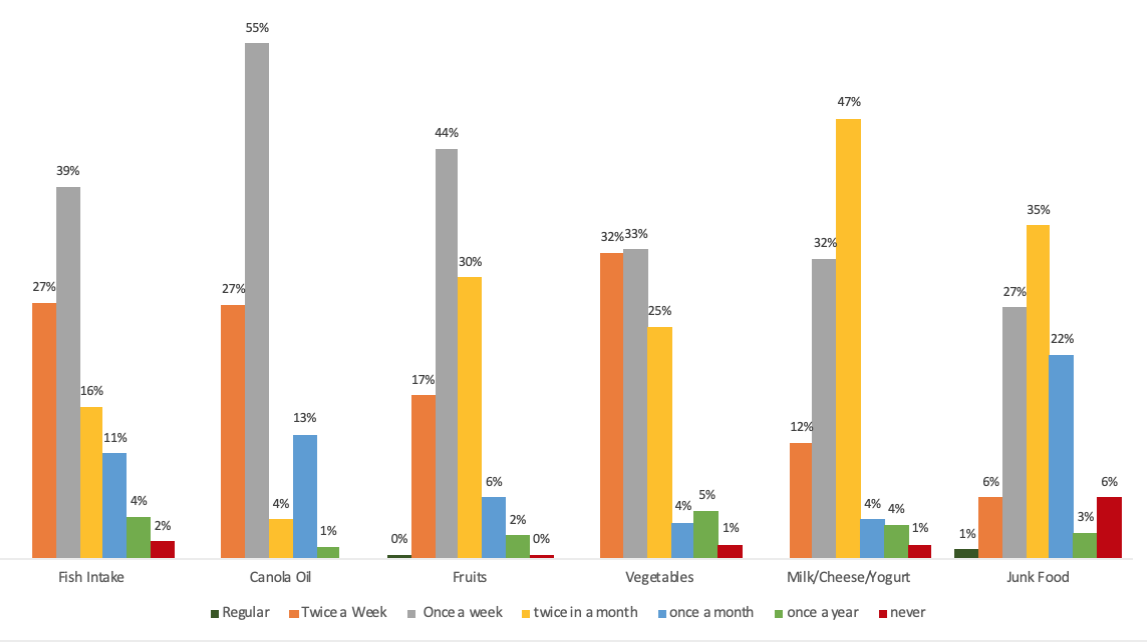

Figure 2: Frequency of the ingestion of various types of food by the study subjects.

While comparing the consumption of food items between fertile and infertile subjects, it was found that fertile subjects responded to have greater intake of fish in comparison with infertile subjects. Fertile females were shown to consume vegetables more frequently and less snack food twice a week $(\mathrm{p}<0.05)$. Moreover, a similar pattern was observed in consumption of fruits $(\mathrm{p}<0.05)$ (Table 2). 


\section{Biosight 2021; 02(02): 30-39}

Table 2: Comparison of the frequency of the consumption of various types of food between fertile and infertile subjects

\begin{tabular}{|c|c|c|c|c|}
\hline & & $\begin{array}{c}\text { Fertile } \\
n=207 \\
n(\%)\end{array}$ & $\begin{array}{c}\text { Infertile } \\
n=135 \\
n(\%)\end{array}$ & P Value \\
\hline \multirow{2}{*}{ Consumption of meals } & Frequent (> 5 times a day) & $100(48 \%)$ & $68(50 \%)$ & 0.87 \\
\hline & Normal (3 times a day) & $107(52 \%)$ & $67(50 \%)$ & 0.75 \\
\hline \multirow{6}{*}{ Fish Intake } & Biweekly & $85(41 \%)$ & $8(6 \%)$ & $<0.05$ \\
\hline & Weekly & $92(44 \%)$ & $43(32 \%)$ & $<0.05$ \\
\hline & Fortnightly & $25(12 \%)$ & $30(22 \%)$ & $<0.05$ \\
\hline & Monthly & $5(2 \%)$ & $33(24 \%)$ & $<0.05$ \\
\hline & Yearly & & $15(11 \%)$ & -- \\
\hline & Never & & $6(4 \%)$ & -- \\
\hline \multirow{5}{*}{ Canola Oil } & Biweekly & $60(29 \%)$ & $32(24 \%)$ & 0.54 \\
\hline & Weekly & $134(65 \%)$ & $53(39 \%)$ & $<0.05$ \\
\hline & Fortnightly & $8(4 \%)$ & $6(4 \%)$ & 0.91 \\
\hline & Monthly & $5(2 \%)$ & $40(30 \%)$ & $<0.05$ \\
\hline & Yearly & & $4(3 \%)$ & -- \\
\hline \multirow{7}{*}{ Fruits } & Regular & & $1(1 \%)$ & -- \\
\hline & Biweekly & $44(21 \%)$ & $15(11 \%)$ & $<0.05$ \\
\hline & Weekly & $97(47 \%)$ & $52(39 \%)$ & 0.78 \\
\hline & Fortnightly & $66(32 \%)$ & $36(27 \%)$ & 0.76 \\
\hline & Monthly & & $22(16 \%)$ & -- \\
\hline & Yearly & & $8(6 \%)$ & -- \\
\hline & never & & $1(1 \%)$ & -- \\
\hline \multirow{6}{*}{ Vegetables } & Biweekly & $82(40 \%)$ & $29(21 \%)$ & $<0.05$ \\
\hline & Weekly & $73(35 \%)$ & $39(29 \%)$ & 0.67 \\
\hline & Fortnightly & $52(25 \%)$ & $32(24 \%)$ & 0.89 \\
\hline & Monthly & & $13(10 \%)$ & -- \\
\hline & Yearly & & $17(13 \%)$ & -- \\
\hline & never & & $5(4 \%)$ & -- \\
\hline \multirow{6}{*}{ Milk/Cheese/Yogurt } & Biweekly & $26(13 \%)$ & $16(12 \%)$ & 0.91 \\
\hline & Weekly & $72(35 \%)$ & $37(27 \%)$ & 0.74 \\
\hline & Fortnightly & $98(47 \%)$ & $62(46 \%)$ & 0.83 \\
\hline & Monthly & $10(5 \%)$ & $4(3 \%)$ & 0.62 \\
\hline & Yearly & $1(0 \%)$ & $11(8 \%)$ & $<0.05$ \\
\hline & never & & $5(4 \%)$ & -- \\
\hline \multirow{7}{*}{ Junk Food } & Regular & & $3(2 \%)$ & -- \\
\hline & Biweekly & $6(3 \%)$ & $16(12 \%)$ & $<0.05$ \\
\hline & Weekly & $60(29 \%)$ & $31(23 \%)$ & 0.61 \\
\hline & Fortnightly & $67(32 \%)$ & $54(40 \%)$ & 0.43 \\
\hline & Monthly & $43(21 \%)$ & $31(23 \%)$ & 0.91 \\
\hline & Yearly & $9(4 \%)$ & & -- \\
\hline & never & $22(11 \%)$ & & -- \\
\hline
\end{tabular}

Values expressed as $\mathrm{n}(\%)$. Groups compared by Pearson Chi Square test; where $\mathrm{p}<0.05$ is considered significant. 


\section{Biosight 2021; 02(02): 30-39}

On evaluating the similar parameters within the subgroups of infertile females, snack food consumption was significant between the groups. Less consumption of vegetables on a frequent basis was consistent in all groups of causes of infertility. Similarly, all the infertile females, irrespective of their cause, consumed less fruits with in the week (Table 3).

Table 3: Comparison of the frequency of the consumption of various items of food in different groups of infertile females

\begin{tabular}{|c|c|c|c|c|c|c|c|}
\hline \multicolumn{2}{|c|}{ Eating Habits } & \multirow{2}{*}{$\begin{array}{c}\begin{array}{c}\text { PCOs } \\
\mathbf{n}=59\end{array} \\
29 \\
(49 \%) \\
\end{array}$} & \multirow{2}{*}{$\begin{array}{c}\begin{array}{c}\text { Male } \\
\text { Factor } \\
\mathbf{n = 1 1}\end{array} \\
3 \\
(27 \%)\end{array}$} & \multirow{2}{*}{$\begin{array}{c}\begin{array}{c}\text { Endometriosis } \\
\mathbf{n}=\mathbf{1 4}\end{array} \\
8(57 \%)\end{array}$} & \multirow{2}{*}{$\begin{array}{c}\begin{array}{c}\text { Tubal } \\
\mathbf{n}=11\end{array} \\
6 \\
(55 \%)\end{array}$} & \multirow{2}{*}{$\begin{array}{c}\begin{array}{c}\text { Unexplained } \\
\mathbf{n}=\mathbf{4 0}\end{array} \\
22(55 \%)\end{array}$} & \multirow{3}{*}{$\begin{array}{c}\mathbf{P} \\
\text { value } \\
\mathbf{0 . 5 5}\end{array}$} \\
\hline \multirow{2}{*}{$\begin{array}{l}\text { Consumpti } \\
\text { on of meals }\end{array}$} & $\begin{array}{l}\text { Frequent (> } 5 \\
\text { times a day) }\end{array}$ & & & & & & \\
\hline & $\begin{array}{l}\text { Normal ( } 3 \\
\text { times a day) }\end{array}$ & $\begin{array}{c}30 \\
(51 \%)\end{array}$ & $\begin{array}{c}8 \\
(73 \%) \\
\end{array}$ & $6(43 \%)$ & $\begin{array}{c}5 \\
(45 \%)\end{array}$ & $18(45 \%)$ & \\
\hline \multirow[t]{6}{*}{ Fish Intake } & Twice a Week & $2(3 \%)$ & $1(9 \%)$ & $3(21 \%)$ & $0(0 \%)$ & $2(5 \%)$ & \multirow[t]{6}{*}{0.35} \\
\hline & Once a week & $\begin{array}{c}21 \\
(36 \%)\end{array}$ & $\begin{array}{c}3 \\
(27 \%)\end{array}$ & $2(14 \%)$ & $\begin{array}{c}4 \\
(36 \%)\end{array}$ & $13(33 \%)$ & \\
\hline & $\begin{array}{l}\text { Twice in a } \\
\text { month }\end{array}$ & $\begin{array}{c}12 \\
(20 \%)\end{array}$ & $\begin{array}{c}4 \\
(36 \%)\end{array}$ & $2(14 \%)$ & $\begin{array}{c}2 \\
(18 \%)\end{array}$ & $10(25 \%)$ & \\
\hline & Once a month & $\begin{array}{c}14 \\
(24 \%)\end{array}$ & $\begin{array}{c}2 \\
(18 \%)\end{array}$ & $5(36 \%)$ & $\begin{array}{c}5 \\
(45 \%)\end{array}$ & $7(18 \%)$ & \\
\hline & Once a year & $9(15 \%)$ & $1(9 \%)$ & $1(7 \%)$ & $0(0 \%)$ & $4(10 \%)$ & \\
\hline & Never & $1(2 \%)$ & $0(0 \%)$ & $1(7 \%)$ & $0(0 \%)$ & $4(10 \%)$ & \\
\hline \multirow[t]{5}{*}{$\begin{array}{l}\text { Canola Oil } \\
\text { Intake }\end{array}$} & Twice a Week & $\begin{array}{c}10 \\
(17 \%)\end{array}$ & $\begin{array}{c}6 \\
(55 \%)\end{array}$ & $4(29 \%)$ & $\begin{array}{c}2 \\
(18 \%)\end{array}$ & $10(25 \%)$ & \multirow[t]{5}{*}{0.56} \\
\hline & Once a week & $\begin{array}{c}25 \\
(42 \%) \\
\end{array}$ & $\begin{array}{c}2 \\
(18 \%) \\
\end{array}$ & $6(43 \%)$ & $\begin{array}{c}6 \\
(55 \%) \\
\end{array}$ & $14(35 \%)$ & \\
\hline & $\begin{array}{l}\text { Twice in a } \\
\text { month }\end{array}$ & $3(5 \%)$ & $0(0 \%)$ & $0(0 \%)$ & $0(0 \%)$ & $3(8 \%)$ & \\
\hline & Once a month & $\begin{array}{c}20 \\
(34 \%)\end{array}$ & $\begin{array}{c}3 \\
(27 \%) \\
\end{array}$ & $4(29 \%)$ & $\begin{array}{c}2 \\
(18 \%)\end{array}$ & $11(28 \%)$ & \\
\hline & Once a year & $1(2 \%)$ & $0(0 \%)$ & $0(0 \%)$ & $1(9 \%)$ & $2(5 \%)$ & \\
\hline \multirow{7}{*}{$\begin{array}{l}\text { Fruits } \\
\text { Intake }\end{array}$} & Regular & $0(0 \%)$ & $0(0 \%)$ & $0(0 \%)$ & $0(0 \%)$ & $1(3 \%)$ & \multirow[t]{7}{*}{0.34} \\
\hline & Twice a Week & $3(5 \%)$ & $\begin{array}{c}2 \\
(18 \%)\end{array}$ & $1(7 \%)$ & $\begin{array}{c}3 \\
(27 \%)\end{array}$ & $6(15 \%)$ & \\
\hline & Once a week & $\begin{array}{c}27 \\
(46 \%) \\
\end{array}$ & $\begin{array}{c}5 \\
(45 \%) \\
\end{array}$ & $4(29 \%)$ & $\begin{array}{c}3 \\
(27 \%) \\
\end{array}$ & $13(33 \%)$ & \\
\hline & $\begin{array}{l}\text { Twice in a } \\
\text { month }\end{array}$ & $\begin{array}{c}19 \\
(32 \%)\end{array}$ & $\begin{array}{c}2 \\
(18 \%) \\
\end{array}$ & $5(36 \%)$ & $\begin{array}{c}2 \\
(18 \%)\end{array}$ & $8(20 \%)$ & \\
\hline & Once a month & $5(8 \%)$ & $\begin{array}{c}2 \\
(18 \%)\end{array}$ & $4(29 \%)$ & $1(9 \%)$ & $10(25 \%)$ & \\
\hline & Once a year & $5(8 \%)$ & $0(0 \%)$ & $0(0 \%)$ & $\begin{array}{c}2 \\
(18 \%)\end{array}$ & $1(3 \%)$ & \\
\hline & Never & $0(0 \%)$ & $0(0 \%)$ & $0(0 \%)$ & $0(0 \%)$ & $1(3 \%)$ & \\
\hline \multirow[t]{2}{*}{$\begin{array}{l}\text { Vegetables } \\
\text { Intake }\end{array}$} & Twice a Week & $\begin{array}{c}12 \\
(20 \%)\end{array}$ & $0(0 \%)$ & $1(7 \%)$ & $\begin{array}{c}2 \\
(18 \%)\end{array}$ & $14(35 \%)$ & \multirow[t]{2}{*}{0.05} \\
\hline & Once a week & 11 & 7 & $3(21 \%)$ & 5 & $13(33 \%)$ & \\
\hline
\end{tabular}


Biosight 2021; 02(02): 30-39

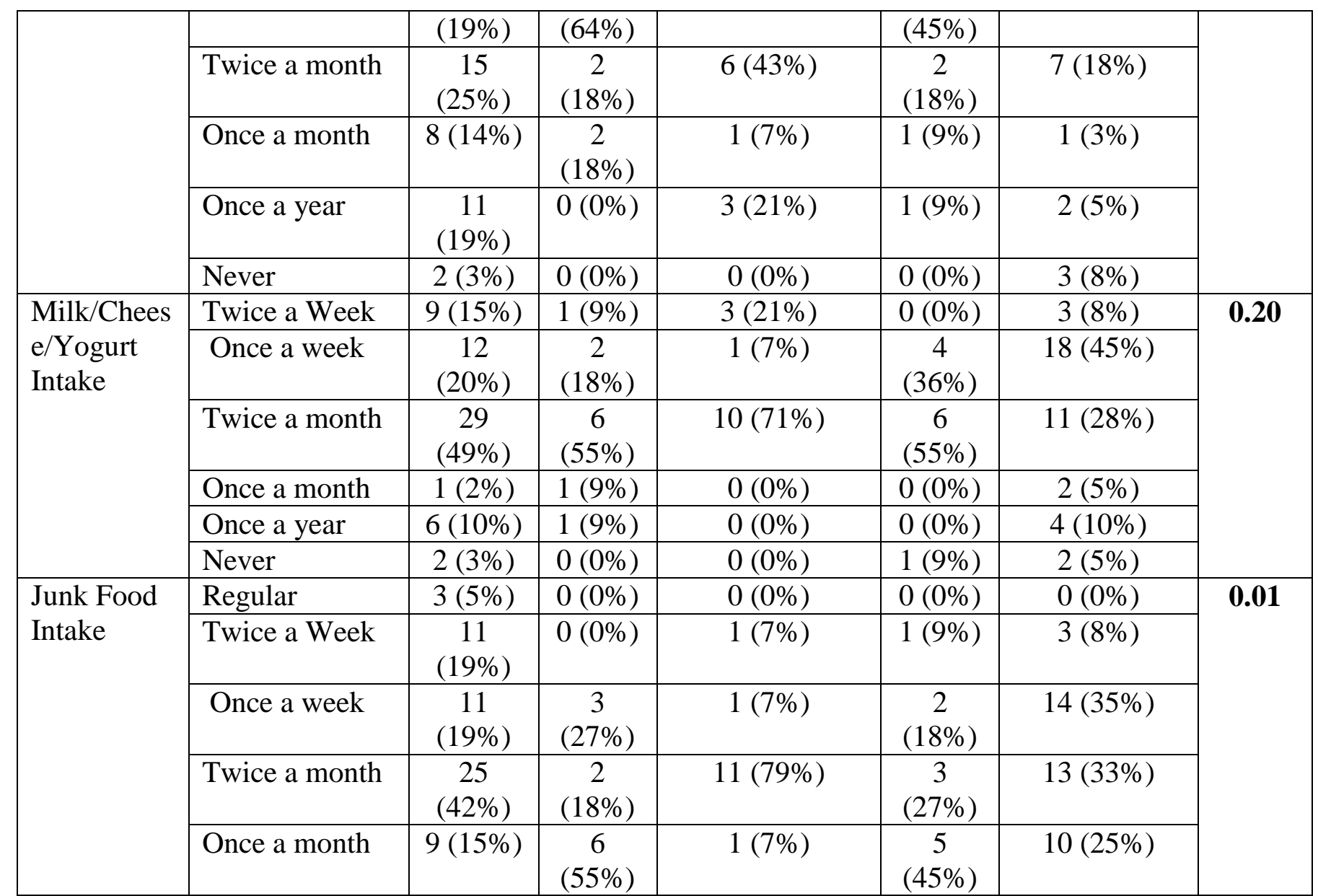

Values expressed as $\mathrm{n}(\%)$. Groups compared by Pearson Chi Square test; where $\mathrm{p}<0.05$ is considered significant.

\section{Discussion}

Infertility is one of the major health concerns and it is important to find creative means to prevent and treat this disease. In our study, we found that infertile females had sedentary lifestyle with increased BMI as compared to fertile females. In a recently conducted large population-based cohort study, effect of PA and BMI was seen in women over a period of 15 years and it was observed that females with high levels of PA had less issues related to their fertility [8]. In line with our results, another study concluded that PA is positively associated with increase in fertility rate [12].

It is well documented that PA is responsible for vasodilation and helped in increased perfusion of many vital organs [13]. Therefore, it is likely that increased blood flow towards reproductive organs helped in ovulation and thus in conception. However, it is moderate levels of exercise which is beneficial for most women and may boost fertility in those with anovulatory disorders such as PCOS, ensuring that it is not excessively strenuous to the degree that it causes energy deficiency as it may further disrupt the ovulatory cycles [14]. Many metabolic disorders and infertility have been linked with a sedentary lifestyle. This lifestyle stimulates the development of the body's oxidants while reducing the antioxidants' ability to fight them. Approximately $34 \%$ of infertile women had a sedentary lifestyle and therefore fall into the obese BMI group $\left(>25 \mathrm{~kg} / \mathrm{m}^{2}\right)$. The results of our research complement these findings. Routine physical activity together with dietary adjustments help to decrease oxidative stress OS [15]. Another research, nevertheless, found that strenuous exercise adversely impacts one's wellbeing in terms of increase in OS aggravation leading to aortic stiffness [16]. 
Another finding in our research showed that females with higher BMI had lower fertility rate. Complex and multifactorial mechanisms are involved in relation to excess body fat and disturbances in reproductive system. By impairing the hypothalamic-pituitary-gonadal (HPG) axis (hyperandrogenism) and the follicular environment, female obesity may affect reproduction [17]. Evidence suggested that the inflammatory pathways of reproductive events; follicle rupture at the time of ovulation and trophoblast invasion into the approachable endometrium are compromised in obese women, [18]. It is important to have knowledge of all the factors leading to infertility, poor eating habits which cause an increase in BMI is therefore an important factor perceived in our study.

As compared to fertile females, infertile females eat more regular meals, which increases glycolysis. Energy-efficient oxidative phosphorylation, instead of energy-inefficient glycolysis, induces metabolic alteration following calorie restriction [19]. Cells increase mitochondrial activity in order to combat this transition and thereby increase the development of free radicals [20]. It is possible that excessive calorie intake exhausts the antioxidant mechanisms, thereby causing the oocytes damage by excessive development of unrecognized reactive oxygen species (ROS).

Food choices play an important role in conception. Our result indicated that females consuming more fish, vegetables and fruits were fertile as compared to those who were eating more junk food. These results were in line with the latest advice from the American College of Gynecologists and Obstetricians, which encouraged to eat a variety of fish in two to three servings a week [21]. However, in contrast to our results another study concluded that higher concentration of mercury in the fish may interfere with fertility therefore; it is also recommended to avoid such fish that contain higher concentration of mercury [22]. Similarly, another retrospective research found that higher fast food frequency and lower fruit and vegetable intake were correlated with longer time in conceiving [23]. The effect of diet rich in vegetables, fruits and fish also influenced the effectiveness of assisted reproductive technique in a study of young non-obese Greek women.

On further stratification of data, decrease intake of vegetables were seen more in females with PCOS as compared to other groups. Our results are consistent with another study that showed decrease intake of vegetable proteins are positively associated with PCOS [24]. Similarly, in another recently conducted randomized control trial, sixty females were allocated in two groups. The group that received more vegetable proteins were likely to have more balanced hormonal profile and attenuation of PCOS symptoms as compared to other group [25]. Therefore, diet could be an effective, appropriate and healthy intervention to alleviate symptoms related to PCOS.

We have tried to elucidate the role of PA, BMI and food habits in relation to fertility in our research, which will help clinician in making policies and offering good advice for clinical practice. However, there are certain limitation, which should be taken into consideration. First, the eating habits were totally based on the information provided by the participant so reporting bias cannot be overruled. Secondly, our sample size was small, which defer generalizability; to make a meaningful difference.

\section{Conclusion:}

Our results suggested that increase physical activity and BMI in optimal range is positively associated with fertility. In addition, dietary habits such as more intake of fish, fruits and vegetables has a positive impact on fertility.

\section{Recommendations}

In connection with other researchers and the outcome of our results, we second the emphasis on the nutritional care, effective counselling and encouragement of couple to take part in PA. The 
Biosight 2021; 02(02): 30-39

best management of women with infertility and chronic anovulation should therefore be effective counselling plans to facilitate weight control, before couple starts ART.

\section{Ethics Approval And Consent To Participate}

Not applicable.

\section{Human And Animal Rights}

No animals were used in this study. The study on humans was conducted in accordance with the ethical rules of the Helsinki Declaration and Good Clinical Practice.

\section{Consent For Publication}

Not applicable.

\section{Availability of Data and Materials}

None.

\section{Funding}

None.

\section{Conflict of Interest}

The authors declare no conflict of interest, financial or otherwise.

\section{Acknowledgements}

Department of Biological and Biomedical Sciences, Aga Khan University, Karachi, Pakistan for their support.

\section{References:}

1. Rehman R, Zafar A, Ali AA, Baig M, Alam F. Impact of serum and follicular fluid kisspeptin and estradiol on oocyte maturity and endometrial thickness among unexplained infertile females during ICSI. PloS one 2020; 15(10): e0239142.

2. Maroufizadeh S, Karimi E, Vesali S, Samani RO. Anxiety and depression after failure of assisted reproductive treatment among patients experiencing infertility. Int J Gynecol Obstetrics 2015; 130(3): 2536.

3. Bala R, Singh V, Rajender S, Singh K. Environment, Lifestyle, and Female Infertility. Reproduc Sci 2020: 1-22.

4. Rehman R, Hussain Z, Fatima SSJIJoRM. Effect of weight status on pregnancy outcome in intra cytoplasmic sperm injection 2013; 11(9): 717-24.

5. Freizinger M, Franko DL, Dacey M, Okun B, Domar AD. The prevalence of eating disorders in infertile women. Fertility and sterility 2010; 93(1): 72-8.

6. Leisegang K, Dutta S. Do lifestyle practices impede male fertility? Andrologia 2020: e13595.

7. Stocker LJ, Cagampang FR, Lu S, Ladyman T, Cheong YC. Is sleep deficit associated with infertility and recurrent pregnancy losses? Results from a prospective cohort study. Acta Obstetricia et Gynecologica Scandinavica 2020.

8. Mena GP, Mielke GI, Brown WJ. Do physical activity, sitting time and body mass index affect fertility over a 15-year period in women? Data from a large population-based cohort study. Human Reproduc 2020; 35(3): 676-83.

9. Grieger JA. Preconception diet, fertility, and later health in pregnancy. Curr Opin Obstetric Gynecol 2020; 32(3): 227-32.

10. Kelsey WE, Kelsey JL, Whittemore AS, Evans AS, Thompson WD. Methods in observational epidemiology: Monographs in Epidemiology and; 1996. 
11. Lim JU, Lee JH, Kim JS, Hwang YI, Kim TH, Lim SY, et al. Comparison of World Health Organization and Asia-Pacific body mass index classifications in COPD patients. Int J Chronic Obstructive Pulmon Dis 2017; 12: 2465-75.

12. Aria B, Salegi-abarghui A, Lotfi MH, Mirzaei M. Effect of exercise, body mass index, and waist to hip ratio on female fertility. J Basic Res Med Sci 2020; 7(3): 19-25.

13. Nystoriak MA, Bhatnagar A. Cardiovascular effects and benefits of exercise. Frontiers in Cardiovascular Med 2018; 5: 135.

14. Hakimi O, Cameron L-C. Effect of exercise on ovulation: a systematic review. Sports Med 2017; 47(8): 1555-1567.

15. Bloomer RJ, Fisher-Wellman KH. Blood oxidative stress biomarkers: influence of sex, exercise training status, and dietary intake. Gender Med 2008; 5(3): 218-28.

16. Jürgenson J, Serg M, Kampus P, Kals J, Zagura M, Viru M, et al. Oxidative stress parameters and its associations with arterial stiffness in competitive powerlifting athletes after 12-week supervised strength training. J Strength Conditioning Res 2019; 33(7): 1816-22.

17. Best D, Avenell A, Bhattacharya S. How effective are weight-loss interventions for improving fertility in women and men who are overweight or obese? A systematic review and meta-analysis of the evidence. Human Reproduc Update 2017; 23(6): 681-705.

18. Broughton DE, Moley KH. Obesity and female infertility: potential mediators of obesity's impact. Fertility Sterility 2017; 107(4): 840-7.

19. Liu Z, Sun Y, Tan S, Liu L, Hu S, Huo H, et al. Nutrient deprivation-related OXPHOS/glycolysis interconversion via HIF-1 $\alpha /$ C-MYC pathway in U251 cells. Tumor Biol 2016; 37(5): 6661-71.

20. Nisoli E, Tonello C, Cardile A, Cozzi V, Bracale R, Tedesco L, et al. Calorie restriction promotes mitochondrial biogenesis by inducing the expression of eNOS. Science 2005; 310(5746): 314-7.

21. Reaffirmed. ACOG Practice advisory: update on seafood consumption during pregnancy: American College of Obstetricians and Gynecologists; 2017 [cited 2020 Januray 2 2021]. Available from: https: //www.acog.org/Clinical-Guidance-and-Publications/Practice-Advisories/ACOG-PracticeAdvisory-Seafood-Consumption-DuringPregnancy.

22. Wise LA, Wesselink AK, Tucker KL, Saklani S, Mikkelsen EM, Cueto H, et al. Dietary fat intake and fecundability in 2 preconception cohort studies. Am J Epidemiol 2018; 187(1): 60-74.

23. Grieger JA, Grzeskowiak LE, Bianco-Miotto T, Jankovic-Karasoulos T, Moran LJ, Wilson RL, et al. Pre-pregnancy fast food and fruit intake is associated with time to pregnancy. Human Reproduc 2018; 33(6): 1063-70.

24. Eslamian G, Hekmatdoost A. Nutrient patterns and risk of polycystic ovary syndrome. J Reproduc Infertility 2019; 20(3): 161-8.

25. Copp T, Cvejic E, McCaffery K, Hersch J, Doust J, Mol BW, et al. Impact of a diagnosis of polycystic ovary syndrome on diet, physical activity and contraceptive use in young women: findings from the Australian Longitudinal Study of Women's Health. Human Reproduc 2020; 35(2): 394-403. 